First publ. in: Protoplasma 186 (1995), 1/2, pp. 1-11

\title{
Sequential deposition of plant glycoproteins and polysaccharides at the host-parasite interface of Uromyces vignae and Vigna sinensis
}

\section{Evidence for endocytosis and secretion}

\author{
M. Stark-Urnau and K. Mendgen* \\ Lehrstuhl für Phytopathologie, Fakultät für Biologịe, Universität Konstanz, Konstanz \\ Received September 7, 1994 \\ Accepted October 18, 1994
}

\begin{abstract}
Summary. Monokaryotic haustoria (M-haustoria) of Uromyces vignae in Vigna sinensis cells are surrounded by an extrahaustorial matrix (ema) and the invaginated host plasmalemma, the extrahaustorial membrane (ehrn). The ema was characterized with antibodies against components of the plant cell wall; the ema contained hydroxyproline-rich glycoproteins and arabinogalactans/arabinogalactan proteins, both at a higher concentration close to the ehm. Haustoria with large vacuoles had the ema encased by additional layers. An electron-translucent inner layer deposited on top of the ema contained arabinogalactans/arabinogalactan proteins, hydroxyprolinerich glycoproteins, and callose. The inner layer was surrounded by an electron-translucent middle layer with numerous dark inclusions, rich in pectin and fucose bound to xyloglucans. Finally, a more electron-dense outer layer containing arabinogalactans/arabinogalactan proteins and hydroxyproline-rich glycoproteins encased the whole structure. These polysaccharides, with the exception of callose and un-esterified pectin, were also found in the plant Golgi apparatus. The polysaccharides were synthesized in the trans Golgi cisternae and secreted into the host-parasite interface. The secretory events seem to be coupled to endocytosis since numerous coated pits were found on the ehm too. The pits were elongated, sometimes formed tubules and the coat reacted with an antibody against plant clathrin. Our results suggest intensive membrane recycling around haustoria, together with the secretion of cell wall material, which in the case of more or less vacuolated haustoria seems to be responsible for encasement
\end{abstract}

Keywords: Monokaryotic haustorium; Encasement; High pressure freezing; Immunolabelling.

Abbreviations: AG/AGP arabinogalactans and arabinogalactan proteins; BSA bovine serum albumin; ehm extrahaustorial membrane;

* Correspondence and reprints: Lehrstuhl für Phytopathologie, Fakultät für Biologie, Universität Konstanz, D-78434 Konstanz, Federal Republic of Germany. ema extrahaustorial matrix; HRGP $2 \mathrm{~b}$ hydroxyproline rich glycoproteins; M-haustorium monokaryotic haustorium; TBS tris buffered saline.

\section{Introduction}

Rust fungi, Uredinales, are biotrophic pathogens which produce intracellular structures within the cells of their hosts. The intracellular structures of the monokaryon of $U$. vignae are either termed intracellular hyphae (Gold et al. 1979, Rijkenberg and Truter 1973), referring to their morphology, or monokaryotic haustoria, referring to their nuclear phase and a proposed functional analogy to dikaryotic haustoria (Harder and Chong 1991, Woods and Gay 1987). In this study, the term M-haustorium will be used according to Littlefield and Heath (1979). In contrast to dikaryotic haustoria which are organized into distinct haustorial body and neck regions (Littlefield and Heath 1979), M-haustoria appear very similar to undifferentiated hyphae and may infect vascular tissue (Larous and Lösel 1993). In all the host cell types the haustorial protoplast is enclosed by the strongly electron-dense fungal wall and the less electron-dense extrahaustorial matrix (ema). The whole structure is surrounded by the invaginated plant plasmalemma, the extrahaustorial membrane (ehm). Haustoria may also be encased by host wall appositions termed papillae or encasements, which separate the fungal 
haustorium from its host cell and are presumed to block nutrient uptake (Heath 1982).

The interface between M-haustoria and their host cells has been investigated ultrastructurally and cytochemically (Harder and Chong 1991, Rijkenberg and Truter 1973, Woods and Gay 1987). However, most components of the ema and possible M-haustoria encasements have not yet been determined (Harder and Chong 1991).

Recently antibodies against glycoproteins and polysaccharides of the plant cell wall have been used as surface markers to investigate the mechanisms underlying early wall development in meristems and embryos (Knox 1992). In the present study, the development of the different layers enclosing $\mathrm{M}$ haustoria was investigated using antibodies specific for the following components of the plant extracellular matrix: hydroxyproline-rich glycoproteins $\left(\mathrm{HRGP}_{2 \mathrm{~b}}\right)$, un-esterified and methyl-esterified pectin, fucose residues on xyloglucans, arabinogalactans and arabinogalactan proteins (AG/AGP), and callose. We show here how these components are secreted at the hostparasite interface and indicate possible functions of the plant Golgi apparatus during encasement.

In non-growing plant cells secretory events are followed by endocytosis in order to maintain a constant cell volume (Steer 1988). Until recently little was known about endocytosis in plants (Fowke et al. 1991, Robinson and Hillmer 1990 a), although endocytosis via clathrin-coated pits is a well studied process in animal cells (Smythe and Warren 1991). Clathrin-coated pits on the plasma membrane of plant cells are supposed to participate in the uptake and recycling of plasma membrane components (Low and Chandra 1994). We suggest that tubular coated pits, observed at the ehm in the tips of M-haustoria, provide evidence for intensive endocytosis at the hostparasite interface. Endocytosis and secretion appear to be coordinated processes and may lead to encasement around $\mathrm{M}$-haustoria.

\section{Materials and methods}

\section{Infected plants}

A 20 day infection of susceptible cowpea (V. sinensis L. cv. California Blackeye) by the pycnial-aecial phase of $U$. vignae (Barclay) was obtained as described (Stark-Urnau and Mendgen 1993).

\section{Preparation of plant material for electron microscopy}

Segments of infected leaf tissue (ca. $2 \mathrm{~cm} \times 2 \mathrm{~cm} \times 0.3 \mathrm{~cm}$ ) were infiltrated with $10 \%$ methanol in distilled water under vacuum $(20 \mathrm{~mm} \mathrm{Hg}$ ) for $2 \mathrm{~min}$ to remove air from intercellular compartments
Table 1. Antibodies

\begin{tabular}{|c|c|c|}
\hline Name & Antigens recognized & Reference \\
\hline JIM5 (m) & un-esterified pectin & Knox et al. 1990 \\
\hline $\operatorname{JIM} 7(\mathrm{~m})$ & methyl-esterified pectin & Knox et al. 1990 \\
\hline CCRC-M1 (m) & $\begin{array}{l}\alpha-(1,2) \text {-linked fucose } \\
\text { residues on xyloglucans }\end{array}$ & Puhlmann et al. 1994 \\
\hline CCRC-M8 (m) & $\begin{array}{l}\beta-(1,6) \text {-galactan } \\
\text { epitopes on } A G / A G P\end{array}$ & M. Hahn pers. comm. \\
\hline $\begin{array}{l}\operatorname{HRGP}_{2 b}(p) \\
(\mathrm{LAM} 2 \mathrm{H} 112 \mathrm{H7})\end{array}$ & $\begin{array}{l}\text { hydroxyproline-rich- } \\
\text { glycoproteins }\end{array}$ & Mazau et al. 1988 \\
\hline Clathrin (p) & heavy chain of clathrin & $\begin{array}{l}\text { D. G. Robinson pers. } \\
\text { comm. }\end{array}$ \\
\hline Callose (m) & $\beta$-(1,3)-glucan & Meikle et al. 1991 \\
\hline
\end{tabular}

$m$ Monoclonal, $p$ polyclonal

(Mendgen et al. 1991). Pieces of leaf tissue were excised using a $2 \mathrm{~mm}$ corkborer, then mounted in hexadecene between two aluminium holders ( $0.3 \mathrm{~mm}$ deep) and cryofixed using a Balzers HPM 010 high pressure freezing apparatus.

Tissues were freeze-substituted with acetone containing $0.5 \%(\mathrm{w} / \mathrm{v})$ osmiumtetroxide at $-90^{\circ} \mathrm{C}$ for $48 \mathrm{~h}$; the temperature was then raised $\left(5^{\circ} \mathrm{C} / \mathrm{h}\right)$ to $-20^{\circ} \mathrm{C}$ using a Reichert $\mathrm{Cs}$-auto cryosubstitution apparatus. Samples were then rinsed in an ethanol/acetone series (30, 50, 70 , and $100 \%$ ethanol in acetone) and infiltrated with LR White resin (The London Resin Co. Ltd, Basingstoke, Hampshire, U.K.) containing $0.5 \%(\mathrm{w} / \mathrm{v})$ benzoin methyl ether for three days at $-20{ }^{\circ} \mathrm{C}$ and polymerized using UV light at $-20^{\circ} \mathrm{C}(24 \mathrm{~h})$ then $+20^{\circ} \mathrm{C}(24 \mathrm{~h})$. Ultrathin sections were mounted on pioloform-coated one slot nickel grids prior to immunolabelling. Some freeze-substituted plant material was embedded in Epon-Araldite resin as described by Knauf et al. (1989).

\section{Antibodies}

The antibodies used for immunochemistry are shown in Table 1. The rat monoclonal JIM7 antibody recognizes methyl-esterified pectin, and the rat monoclonal JIM5 antibody recognizes un-esterified pectin (Knox et al. 1990). The mouse monoclonal CCRC-M1 antibody (Puhlmann et al. 1994) chiefly recognizes the terminal $\alpha$ - $(1,2)$-linked fucosyl residue of the trisaccharide side chain of xyloglucan within an extended xyloglucan chain. The mouse monoclonal CCRC-M8 recognizes arabinosylated $\beta-(1,6)$-galactan epitopes on arabinogalactans and arabinogalactan proteins ( $\mathrm{M}$. Hahn pers. comm.). The polyclonal antiserum obtained in rabbit against the major glycoprotein fraction, designated HRGP $_{2 \mathrm{~b}}$, was isolated from melon callus (Cucumis melo) (Mazau et al. 1988). Callose was detected with a mouse monoclonal antibody against tetra- to octasaccharides of $\beta-(1,3)$-glucan (Meikle et al. 1991; purchased from Biosupplies, Parkville, Victoria, Australia). The anti-clathrin polyclonal antiserum prepared from clathrin coated vesicles was isolated from etiolated zucchini hypocotyls (Cucurbita pepo L. var. Cocozelle von Tripolis), and recognizes plant, but not brain, clathrin heavy chains (D. Robinson pers. comm).

\section{Immunogold-labelling}

Tris buffered saline (TBS) buffer (10 mM Tris-HCl, pH 7.4, $150 \mathrm{mM}$ $\left.\mathrm{NaCl}, 0.02 \%(\mathrm{w} / \mathrm{v}) \mathrm{NaN}_{3}\right)$ containing different additives was used for 

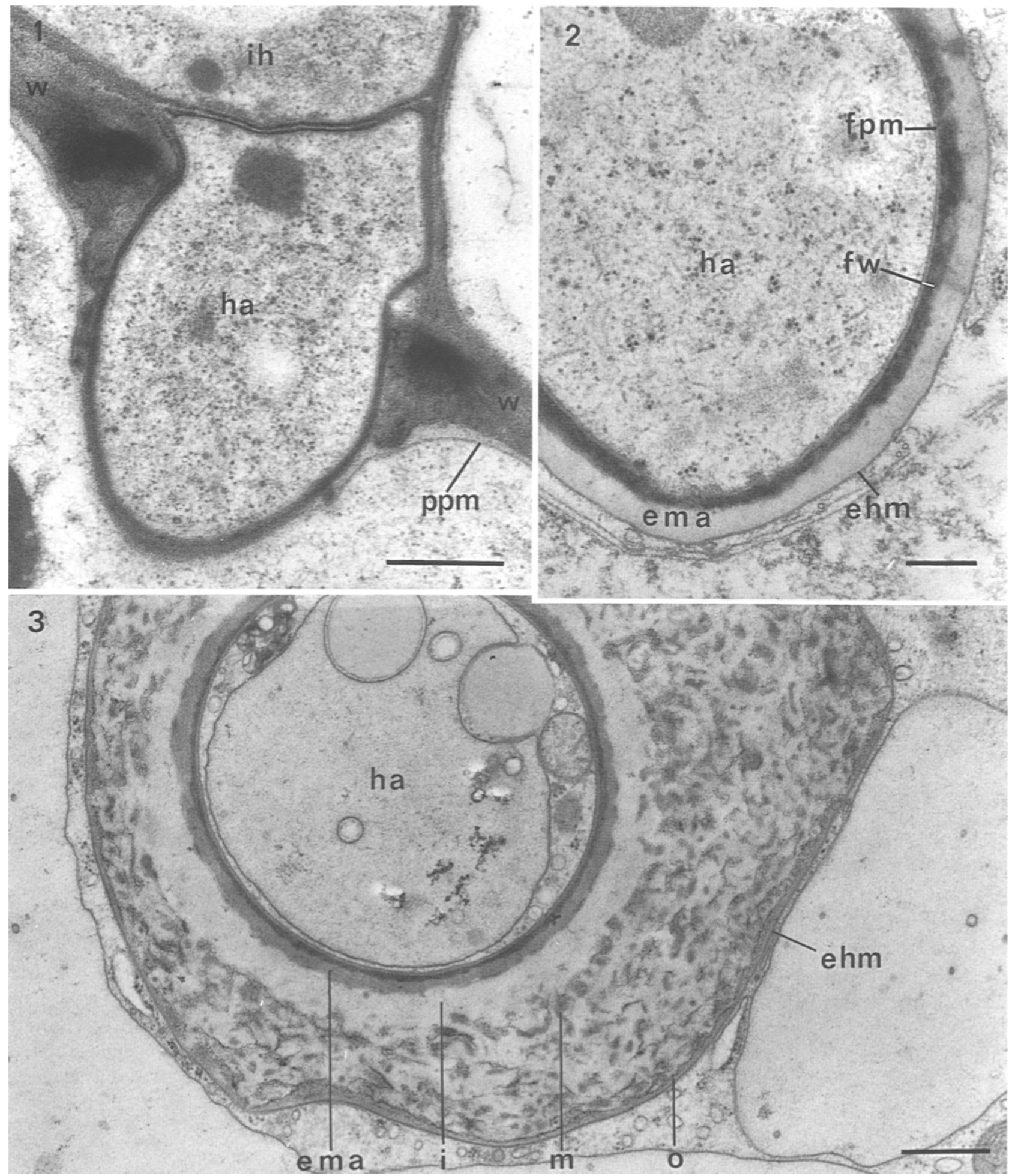

Fig. 1. Electron micrograph of a young $\mathrm{M}$-haustoriurn (ha) of $U$. vignae penetrating the host cell wall (w), and invaginating the plant plasmalemma $(p p m)$. LR White resin. ih Intercellular hypha. Bar: $0.5 \mu \mathrm{m}$

Figs. 2 and 3. Electron micrographs of $M$-haustoria of $U$. vignae embedded in Epon-Araldite resin

Fig. 2. M-haustorium ( $h a$ ) with fungal plasmalemma ( $\mathrm{pm}$ ), fungal wall ( $\mathrm{fw}$ ), extrahaustorial matrix (ema) and extrahaustorial membrane (ehm). Bar: $0.2 \mu \mathrm{m}$

Fig. 3. Vacuolated $M$-haustorium (ha) in a host cell, enclosed by a layered encasement: the extrahaustorial matrix (ema) is enclosed by an inner layer $(i)$ followed by a middle $(m)$ and an outer layer $(o)$. The encasement is surrounded by the extrahaustorial membrane $(e h m)$. Bar: $0.5 \mu m$ 
all rinsing steps and to dilute antisera. The additives included $0.5 \%$ bovine serum albumin (Serva, Heidelberg, Federal Republic of Germany) for JIM5, JIM7 and CCRC-M1; $0.5 \%$ bovine serum albumin plus $1 \%(\mathrm{v} / \mathrm{v})$ cold water fish skin gelatin (Fluka, Buchs, Switzerland) for $\beta-(1,3)$-glucan; and $3 \%$ bovine serum albumin plus $0.05 \%(\mathrm{v} / \mathrm{v})$ Tween 20 for CCRC-M8, clathrin and $\mathrm{HRGP}_{2 \mathrm{~b}}$.

Sections were immunolabelled by immersing grids in drops $(20 \mathrm{ml})$ of reagent on parafilm. The following protocol was used. The grids were incubated in TBS buffer (containing different additives described above) at $22{ }^{\circ} \mathrm{C}$ for $1 \mathrm{~h}$. They were immersed in primary antisera diluted in TBS for $14 \mathrm{~h}$ at $4{ }^{\circ} \mathrm{C}$. JIM5 and CCRC-M8 were diluted $1: 10$, JIM7 and CCRC-M1 were diluted $1: 1$; monoclonal anti- $\beta$ - $(1,3)$-glucan antibody was diluted $1: 20$, and antisera to $\mathrm{HRGP}_{2 \mathrm{~b}}$ and clathrin were diluted $1: 500$. The grids were then washed twice with TBS for $30 \mathrm{~min}$ before being incubated with secondary antisera (Plano Planet GmbH, Marburg, Federal Republic of Germany) diluted $1: 20$ in TBS for $1 \mathrm{~h}$ at $22^{\circ} \mathrm{C}$. The secondary antisera were goat anti-rat IgG labelled with $15 \mathrm{~nm}$ gold particles for JIM5 and JIM7; goat anti-mouse IgG/M labelled with $15 \mathrm{~nm}$ gold particles for CCRC-M1, CCRC-M8 and monoclonal anti- $\beta$ - $(1,3)$-glucan; and finally goat anti-rabbit IgG conjugated with $10 \mathrm{~nm}$ gold particles for $\mathrm{HRGP}_{2 \mathrm{~b}}$ and clathrin. Excess secondary antibody was removed by rinsing with TBS buffer followed by rinsing with distilled water. Sections were then fixed for $15 \mathrm{~min}$ with $2 \%$ aqueous glutaraldehyde and washed with distilled water. The specificity of antibody labelling was determined by replacing the primary antibody with buffer. Sections were stained with uranyl-acetate and lead citrate and viewed with a Zeiss EM 10CR or a Hitachi H7000 TEM.

\section{Results}

M-haustoria invaginated the host plasma membrane after penetrating the host cell wall (Fig. 1). The fungal plasma membrane was surrounded by darkly stained fungal wall and the ema (Fig. 2). Such haustoria had a dense cytoplasm with many ribosomes and mitochondria suggesting active nutrient uptake. Other obviously older M-haustoria contained many large vacuoles and the ema was covered by additional layers, up to $1.8 \mu \mathrm{m}$ thick (Fig. 3), forming an encasement. In Epon-Araldite embedded material an inner electron-translucent, a middle electron-translucent layer with numerous dark inclusions, and a slim outer slightly electron-dense layer were observed, deposited on top of the ema. After embedding in LR-White, the different layers were lower in contrast and were often difficult to distinguish (Figs. $4 \mathrm{~b}$ and $5 \mathrm{~b}$ ).

Antibodies against AG/AGP (CCRC-M8) labelled the ema of all M-haustoria with greater intensity close to the ehm (Fig. 4 a). In encased M-haustoria, the antibody labelled the inner layer, and the outer layer beside the ehm. The AG/AGP-antibodies also labelled the plant tonoplast (Fig. 4 b), and uninvaginated plant plasma membrane with plant cell wall (Fig. $4 \mathrm{c}$ ), and the trans-cisternae of the plant Golgi apparatus (Fig. $4 \mathrm{~d}$ ).

A very similar labelling pattern was obtained with an antibody recognizing HRGP $_{2 b}$ (Fig. 5 a-d). It labelled the ema of all M-haustoria (Fig. 5 a) in the inner and outer layer of the encasement (Fig. $5 \mathrm{~b}$ ). In addition, the $\mathrm{HRGP}_{2 \mathrm{~b}}$ antibody labelled the plant plasma membrane, plant cell wall (Fig. $5 \mathrm{c}$ ), trans-cisternae of the plant Golgi apparatus and adjacent vesicles (Fig. 5 d), but not the tonoplast (data not shown).

The antibody raised against $\beta$-(1,3)-glucans (callose) labelled the inner electron-translucent layer of the haustorial encasement (Fig. 6). This antibody labelled neither the plant cell wall nor the cisternae of the plant Golgi apparatus.

Antibodies raised against fucose residues on xyloglucans (CCRC-M1), methyl-esterified pectin (JIM7) and un-esterified pectin (JIM5) labelled the middle layer of haustorial encasements (Figs. $7 \mathrm{a}, 8 \mathrm{a}$, and 9 a) as well as the plant cell wall (Figs. 7 b, 8 b, and $9 \mathrm{~b}$ ). These structures were labelled more strongly by the antibody raised against un-esterified pectin (JIM5) than by the other antibodies (Figs. 7 a, b, 8 a, $b$, and $9 \mathrm{a}, \mathrm{b})$. Fucosyl residues on xyloglucans (Fig. 7 c) and methyl-esterified pectin (Fig. 8 b), but not un-esterified pectin, were detected in the transcisternae of plant Golgi apparatus and trans Golgi network.

Numerous coated pits (diameter ca. 50-70 nm; Fig. 10), sometimes forming long tubules which extended into the plant cytoplasm, were found at the

Fig. 4 a-d. Immunogold-labelling of AG/AGP (CCRC-M8) on M-haustoria, encasement, plant cell wall, and plant Golgi apparatus. Bar (in d): $0.5 \mu \mathrm{m}$. a Most gold particles are associated with the ehm and ema. b Labelling of ema, the inner $(i)$ and outer layer $(o)$ of the encasement. The tonoplast $(t)$ is also labelled. $\mathbf{c}$ The plant plasmalemma and the plant cell wall $(w)$ adjacent to the plasma membrane are labelled. $\mathbf{d}$ In plant cytoplasm trans Golgi cisternae ( $t r$ ) are heavily labelled (small arrows); $c$ cis Golgi cisternae. EM; LR White resin

Fig. 5 a-d. Immunogold-labelling of $\mathrm{HRGP}_{2 \mathrm{~b}}$ on M-haustoria, encasement and plant Golgi apparatus. Bar (in d): 0.5 um. a Labelling is restricted to the ema. b Labelling of ema, the inner ( $i)$ and outer layer ( $o$ ) of the encasement. $\mathbf{c}$ The plant plasmalemma and the plant cell wall $(w)$ adjacent to the plasma membrane are labelled. $\mathbf{d}$ Trans Golgi cisternae $(t r)$ and adjacent vesicles in host cytoplasm are labelled (small arrows); $c$ cis Golgi cisternae; EM; LR White resin 

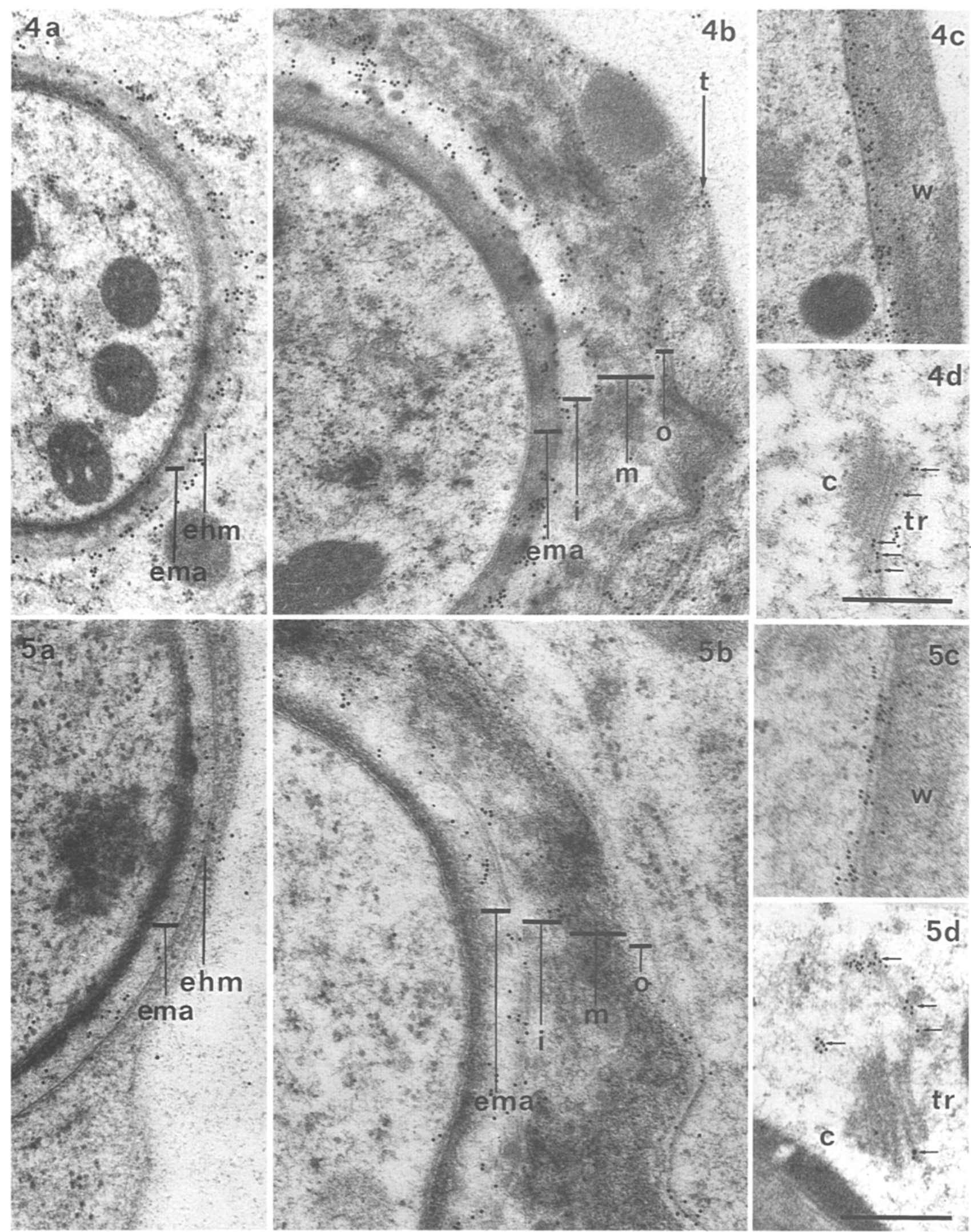
ehm in the tip region of M-haustoria with dense cytoplasm. The coat was labelled by an antibody recognizing the heavy chain of clathrin (Fig. 11). The anticlathrin antibody also labelled, although quite weakly, the plant plasmalemma, the trans-cisternae of the plant Golgi apparatus, and the tonoplast (data not shown).

\section{Discussion}

Collar-forming papillae and cell wall-like encasements are common features of incompatible host-parasite interactions (Cohen et al. 1990, Heath 1971). However, during investigation of the monokaryotic phase of compatible interactions, haustorial encasement was also frequently observed (Harder 1978, Rijkenberg and Truter 1973, Woods and Gay 1987). Here we show that encasements are produced by the secretion of cell wall material at the host-parasite interface in compatible interactions. The encasement consisted of several layers composed of different constituents of the plant cell wall (Fig. 12). Encasements were mostly found around late stages of M-haustoria which are probably no longer functioning.

In the ema of M-haustoria AG/AGP concentration was highest close to the ehm. AG/AGP was also found on the plant cell wall adjacent to the plasma membrane. This agrees with observations by Pennell et al. (1989) who propose that arabinogalactans have the property of binding to $\beta$-glucans and serve as cell surface attachment sites for cell wall matrix polysaccharides. The detection of AG/AGP in the trans-cisternae of the plant Golgi apparatus, as seen by Zhang and Staehelin (1992) in sycamore maple suspension culture cells, suggests that the addition of arabinose sidechains to the galacturonan-backbone occurs in the trans cisternae of the plant Golgi apparatus. Most of the antibodies generated against components of the plant cell wall recognize immunodominant arabino- galactans or arabinogalactan proteins (Knox 1992, Pennell et al. 1989, Pennell 1992). The CCRC-M8 antibody against arabinosylated $\beta-(1,6)$-galactan epitopes on AG/AGP does not cross-react with gum arabic, in contrast to other monoclonal antibodies to arabinogalactans (Puhlmann et al. 1994).

Another component of the ema was HRGP $2 \mathrm{~b}$. HRGP $2 \mathrm{~b}$ was also detected in the plant cell wall close to the plasmalemma. Furthermore, we detected $\mathrm{HRGP}_{2 b}$ in the trans cisternae of the Golgi apparatus where it is believed to be glycosylated. Our observations correspond to those of Grief and Shaw (1987) who describe HRGP (extensin) synthesis in the Golgi apparatus of Chlamydomonas reinhardtii, except that they observed labelling of medial and trans Golgi cisternae. The somewhat different labelling patterns of the Golgi cisternae might be due to different species and cell types.

The inner layer of extrahaustorial encasements (adjacent to the ema) contained AG/AGP, HRGP, and $\beta$ $(1,3)$-glucans (callose). Callose is a common constituent of encasements and papillae (Heath 1982). In plant tissue callose is synthesized by the $\beta$ - $(1,3)$-glucan synthase which is localized at the plasmalemma (Kauss 1994). Thus callose appears to be synthesized directly at the ehm forming the inner layer of the encasement. The antibody did not label the fungal cell wall and was confined to the electron-translucent layer of the encasement. We therefore conclude that, during an early period of encasement production, the inner layer is produced by transient activation of the synthase, localized in the ehm. In later stages of encasement the enzyme could be inactivated or callose epitopes hidden by other components of the plant cell wall and thus no longer detected.

The middle layer of the encasement contained fucosylated xyloglucans and methyl-esterified and unesterified pectin. Fucosylated xyloglucans and methylesterified pectin seem to be synthesized by, and

Fig. 6. Immunogold-labelling with anti-callose antibodies. Note that the gold particles are concentrated over the inner layer $(i)$ of the encasement. Bar: $0.5 \mu \mathrm{m}$. EM; LR White resin

Fig. 7 a-c. Immunogold-labelling of fucose residues of xyloglucans (CCRC-M1) on encasement, plant cell wall, and plant Golgi apparatus. Bar (in c): $0.5 \mu \mathrm{m}$. a Gold particles are obvious over the middle layer $(m)$ with some reaching into the inner layer $(i)$ of the encasement. $\mathbf{b}$ Labelling of the plant cell wall $(w)$ of two adjacent mesophyll cells. $\mathbf{c}$ The medial and trans cisternae of plant Golgi ( $t r$ ) are labelled (small arrows); $c$ cis Golgi cisternae; EM; LR White resin

Fig. 8 a, b. Immunogold-labelling of methyl-esterified pectin (JIM7) on encasement, plant cell wall, and plant Golgi apparatus. Bar (in b): $0.5 \mu \mathrm{m}$. a Gold particles are restricted to the middle layer $(m)$ of the encasement. b The plant cell wall ( $w$ ) and the medial and trans Golgi cisternae $(t r)$ are labelled (small arrows); $c$ cis Golgi cisternae; EM; LR White resin 

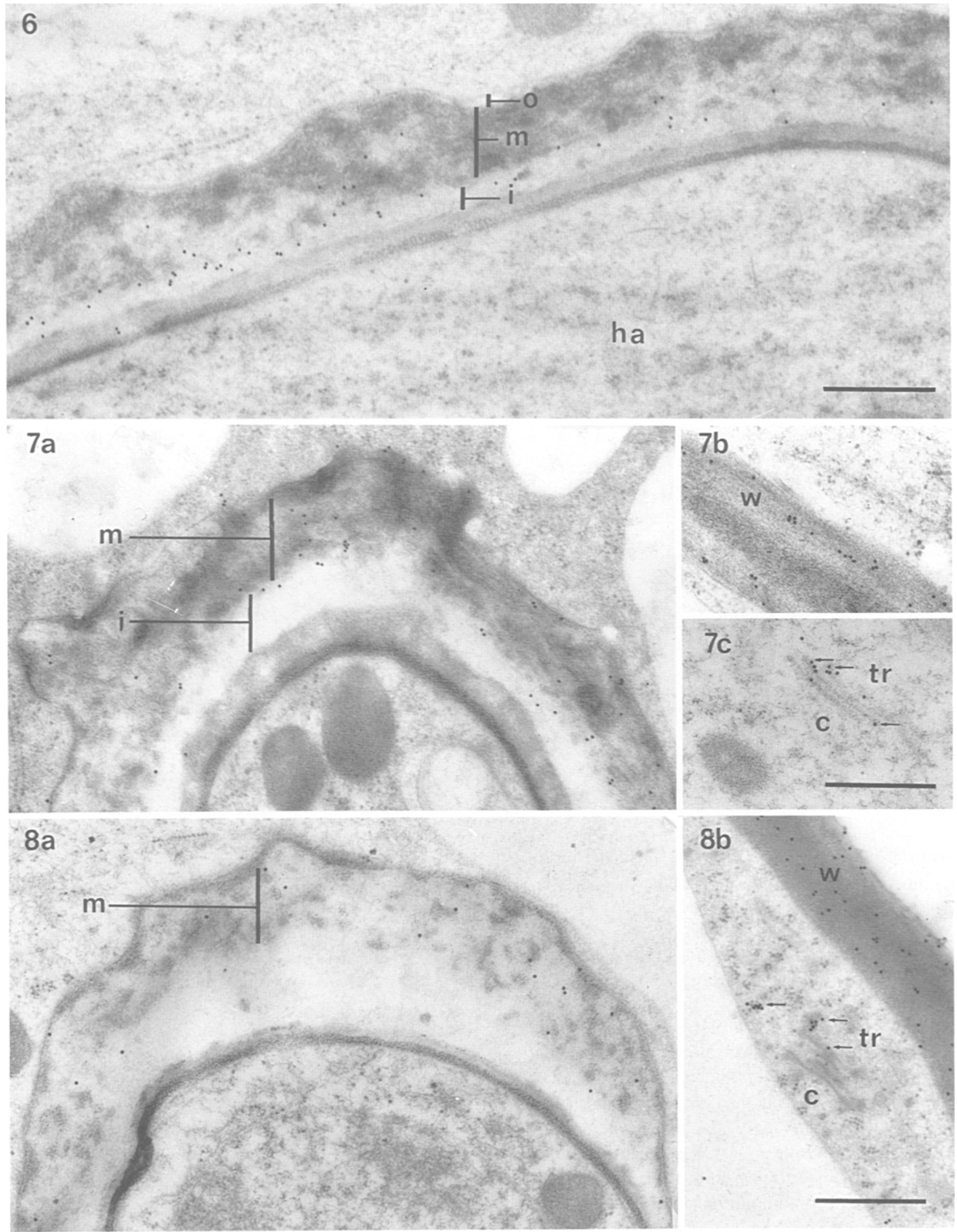


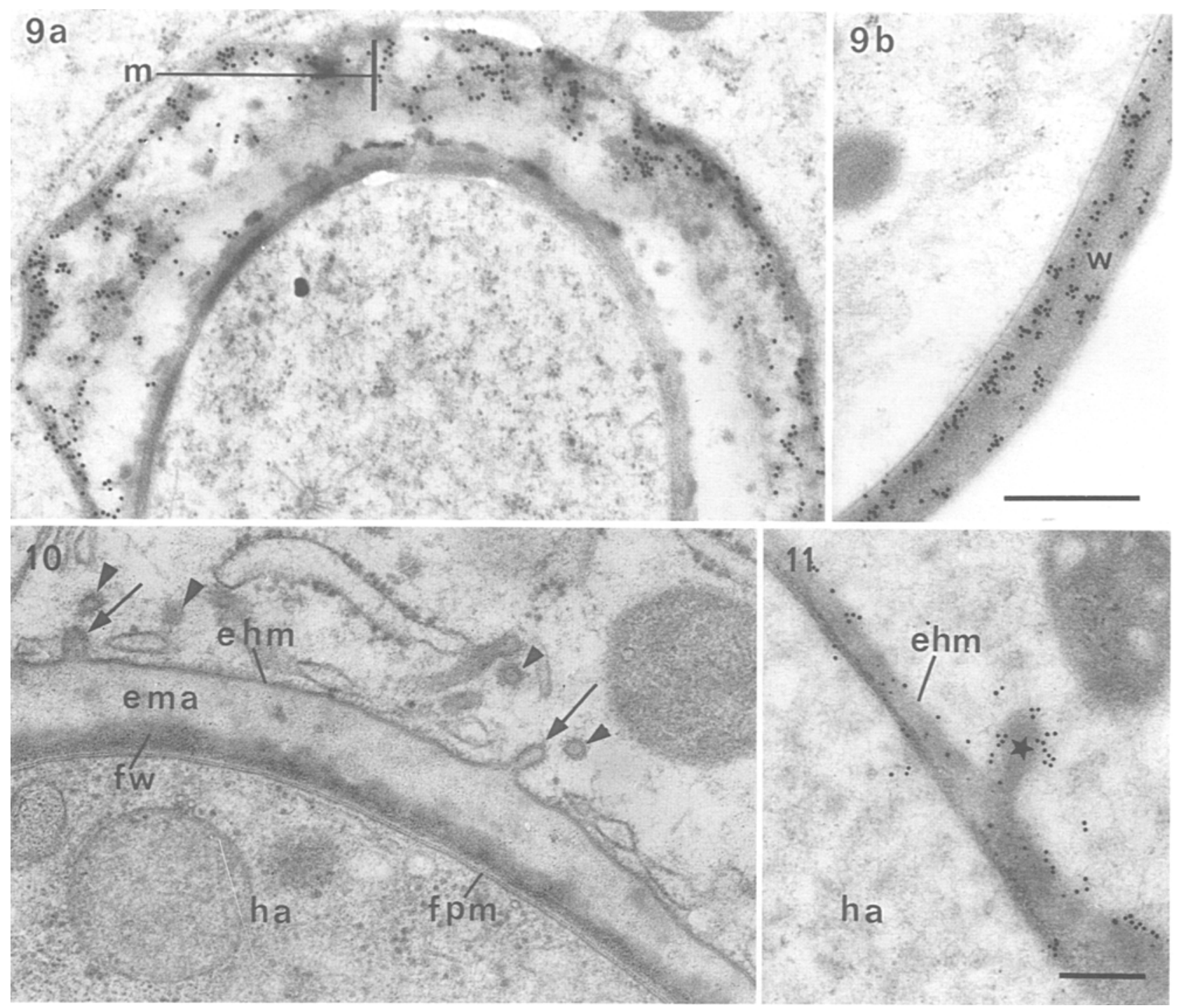

Fig. 9 a, b. Immunogold-labelling of un-esterified pectin (JIM5) and plant cell wall. Bar (in b): $0.5 \mu \mathrm{m}$. a Gold particles are restricted to the middle layer $(m)$ of the encasement. b Labelling of the plant cell wall $(w)$. EM; LR White resin

Fig. 10. Coated pits (arrows) are found on the extrahaustorial membrane (ehm) enclosing M-haustoria (ha) and in the host cytoplasm (arrowheads). The fungal plasmalemma ( $f p m$ ) is enclosed by the fungal wall ( $f w$ ) which is surrounded by the extrahaustorial matrix (ema). EM; EponAraldite resin; same magnification as Fig. 11

Fig. 11. Immunogold-labelling of coated pit (star) with the anti-clathrin antibody. EM; LR White resin; bar : $0.2 \mu \mathrm{m}$

secreted from the trans Golgi apparatus. This conclusion is in line with electron microscopical studies of Moore et al. (1991) and Zhang and Staehelin (1992) who suggest that the Golgi apparatus is the site of xyloglucan and polygalacturonic acid/rhamnogalacturonan I synthesis. Unlike the antibody recognizing methyl-esterified pectin, the antibody against un-esterified pectin did not label the Golgi apparatus. This difference could be due to secretion of pectin in a methyl-esterified form that is later de-esterified in the cell wall and/or encasement (Roberts 1990, Sherrier and Vandenbosch 1994).

Encasement was completed by the small outer layer containing AG/AGP and HRGP $2 \mathrm{~b}$ (Figs. $4 \mathrm{~b}$ and 5 b). Our observation of both $\mathrm{AG} / \mathrm{AGP}$ and $\mathrm{HRGP}_{2 b}$ in the inner and outer layer of encasements, but not in the middle layer (Fig. 12), supports the view that the different layers of the encasement are produced sequentially. I.e., secretion occurs step-by-step in a highly regulated fashion producing different layers. 


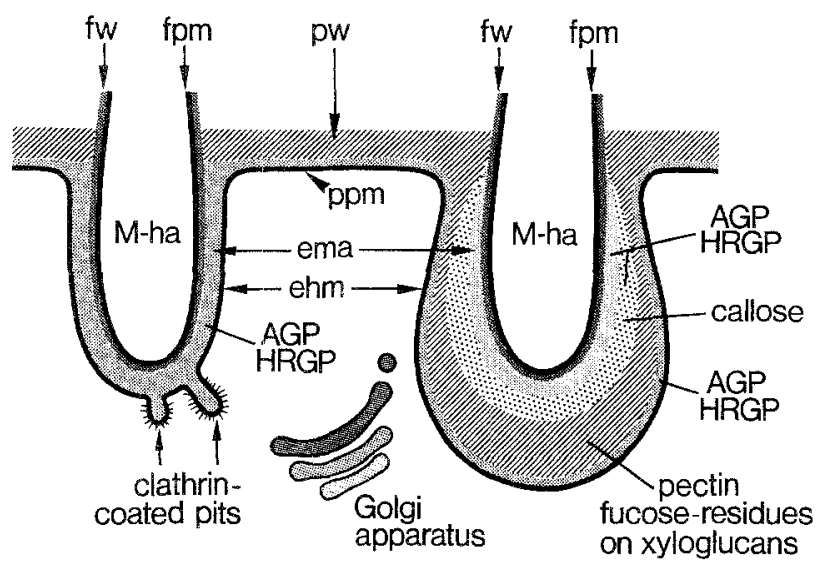

Fig. 12. Diagrammatic representation of the two forms of M-haustoria. Arabinogalactan proteins $(A G P)$, extrahaustorial matrix (ema), extrahaustorial membrane (ehm), fungal wall $(f w)$, fungal plasmalemma $(f p m)$, hydroxyproline-rich glycoproteins (HRGP), M-haustorium $(M-h a)$, plant plasmalemma $(p p m)$, plant cell wall $(p w)$

This contrasts with single layered host-parasite interfaces of mycorrhizal cells from Glomus versiforme, where deposition of plant cell wall polysaccharides, such as un-esterified pectin and hydroxyproline-rich glycoproteins at the host-parasite interface, has also been detected (Bonfante-Fasolo et al. 1992). Furthermore, Bradley et al. (1988) observed labelling of peribacteroid membranes of Rhizobium leguminosarum and plant plasma membrane of Pisum sativum with arabinogalactan antibodies (MAC 209). Their labelling pattern is similar to the result we obtained with the AG/AGP-antibody (CCRC-M-8), the ema was labelled close to the ehm (Fig. 5 a, c).

As described before, exocytotic events are usually coupled to endocytotic phenomena (Steer 1988). Endocytosis at the host-parasite interface might recycle plasmalemma material after exocytosis of glycoproteins (HRGP $2 \mathrm{~b}, \mathrm{AG} / \mathrm{AGP})$ and polysaccharides into the ema. This phenomenon has been discussed as essential for the maintenance of cell volume during secretion in non-growing cells (Steer 1988, Oparka 1993). Since tubular coated pits, continuous with the ehm, were observed mostly at the tip of M-haustoria it seems that endocytotic processes are most active during extension growth of M-haustoria. In uredinial infections of Puccinia coronata $\mathrm{f}$. sp. avenae and $P$. graminis f. sp. tritici, tubular complexes consisting of large and small tubules were also formed at the ehm (Harder et al. 1978, Harder 1978, Harder and Chong 1991). These tubular complexes are thought to be part of the host response to infection. The large tubules were bounded by lightly stained membranes, whereas the small tubules stained more darkly. However, no clathrin-like coat on the tubular complexes was recorded (Harder et al. 1978).

Using an antibody against plant clathrin heavy chain, we have located clathrin on tubular coated pits at the ehm of M-haustoria. Clathrin is generally considered as a marker for endocytotic events (Low and Chandra 1994). There is increasing evidence that receptormediated endocytosis via clathrin coated pits also occurs in plants (Robinson and Hillmer 1990b). A $\beta$ type adaptin has recently been identified in plant coated vesicles (Holstein et al. 1994) and there is good evidence for the presence of receptors for fungal elicitors at the plant plasmalemma (Ebel and Cosio 1994). In host-parasite interactions receptor-mediated endocytosis of fungal elicitor molecules might be of great importance (Cheong and Hahn 1991, Schmidt and Ebel 1987). It is interesting to note that the coated pits observed around haustoria may differ morphologically from those generally observed in plants (Robinson and Hillmer 1990b). They can be more elongated and extend into the plant cytoplasm. Nearby coated vesicles had the typical vesicular shape. Perhaps the "pinching off" process is somewhat delayed around haustoria or differs from the usual process. Many fungi produce the macrocyclic lacton Brefeldin A which induces tubulation of Golgi membranes (Cluett et al. 1993). Rust fungi also seem to be able to induce tubule-formation at the extrahaustorial membrane.

This study shows that secretion of plant carbohydrates and endocytosis via coated pits are coupled events at the host-parasite interface. The secretion of the different cell wall constituents takes place sequentially and may completely encase older haustoria. The mechanism that induces haustorium encasement is still poorly understood. Heath (1988) has shown that haustoria inactivated by inhibitors become completely encased. She suggests that active haustoria suppress defence reactions of the host cell. Therefore it seems that vacuolate haustoria are inactivated and consequently become encased.

\section{Acknowledgements}

We gratefully acknowledge kind gifts of antibodies from Dr. Paul Knox (Plant Biotechnology Centre, Leeds University, Leeds, U.K.), Dr. Marie Thérèse Esquerré-Tugayé (Université Paul Sabatier, Centre de Physiologie Végétale, Toulouse, France), Dr. Michael Hahn (Complex Carbohydrate Research Centre, University of Georgia, Athens, GA, U.S.A.) and Dr. David Robinson (University Göttingen, Göttingen, Federal Republic of Germany). We thank Drs. 
Richard O'Connel and David Robinson for their helpful suggestions and comments on the manuscript.

The project was supported by the Deutsche Forschungsgemeinschaft.

\section{References}

Al-Khesraji TO, Lösel DM (1981) The fine structure of haustoria, intracellular hyphae and intercellular hyphae of Puccinia poarum. Physiol Plant Pathol 19: 301-311

Bofante-Fasolo P, Peretto R, Perotto S (1992) Cell surface interactions in endomycorrhizal symbiosis. In: Callow JA, Green JR (eds) Perspectives in plant cell recognition. Cambridge University Press, Cambridge, pp 239-255

Bradley DJ, Wood EA, Larkins AP, Galfre G, Butcher GW, Brewin NJ (1988) Isolation of monoclonal antibodies reacting with peribacteroid membranes and other components of pea root nodules containing Rhizobium leguminosarium. Planta 173: 149-160

Cheong JJ, Hahn M (1991) A specific high-affinity binding site for the hepta- $\beta$-glucoside elicitor exists in soybean membranes. Plant Cell 3: 137-147

Cluett EB, Wood SA, Banta M, Brown WJ (1993) Tubulation of Golgi membranes in vivo and in vitro in the absence of Brefeldin-A. J Cell Biol 120: 15-24

Cohen Y, Eyal H, Hanania J (1990) Ultrastructure, autofluorescence, callose deposition and lignification in susceptible and resistant muskmelon leaves infected with powdery mildew fungus Sphaerotheca fuliginea. Physiol Mol Plant Pathol 36: 191-204

Cosio FG, Frey T, Ebel J (1990) Solubilization of soybean membrane binding sites for fungal $\beta$-glucans that elicit phytoalexin accumulation. FEBS 264: 235-238

Ebel J, Cosio FG (1994) Elicitors of plant defense responses. Int Rev Cytol 148: 1-36

Fowke LC, Tanchak MA, Galway ME (1991) Ultrastructural cytology of the endocytotic pathway in plants. In: Hawes CR, Evans DE, Coleman JOD (eds) Endocytosis and vesicle traffic in plants. Cambridge University Press, Cambridge, pp 15-40

Gold RE, Littlefield LH, Statler ED (1979) Ultrastructure of the pycnial and aecial stages of Puccinia recondita. Can J Bot 57: 74-86

Grief G, Shaw PJ (1987) Assembly of cell wall glycoproteins of Chlamydomonas reinhardtii: oligosaccharides are added in the medial and trans Golgi compartments. Planta 171: 302-312

Harder DE (1979) Comparative ultrastructure of the haustoria in uredial and pyenial infections of Puccinia coronata avenae. Can J Bot 56: 214-224

- Chong J (1991) Rust haustoria. In: Mendgen K, Lesemann DE (eds) Electron microscopy of plant pathogens. Springer, Berlin Heidelberg New York Tokyo, pp 235-250

- Rohringer RJSD, Kim WK, Chong J (1978) Electron microscopy of susceptible and resistant near-isogenic (sr6/Sr6) lines of wheat infected Puccinia graminis tritici. I. The host-pathogen interface in the compatible (sr6/P6) interaction. Can J Bot 56: 2955-2966

Heath MC (1971) Haustorial sheath formation in cowpea leaves immune to rust infection. Phytopathology 61: 383-388

- (1982) Host defence mechanisms against infection by rust fungi. In: Scott KJ, Chakravorty AK (eds) The rust fungi. Academic Press, London, pp 223-245

- (1988) Effect of fungal death or inhibition induced by oxycarboxin or polyoxin $\mathrm{D}$ on the interaction between resistant or sus- ceptible bean cultivars and the bean rust fungus. Phytopathology 78: 1454-1462

Holstein SEH, Daneker M, Robinson DG (1994) Identification of a $\beta$-type adaptin in plant clathrin-coated vesicles. J Cell Sci 107: 945-953

Kauss H (1994) Callose synthesis. In: Smallwood M, Knox P, Bowles DJ (eds) Specialized functions in plant cells. JAI Press, London, pp 609-631

Knauf G, Welter K, Müller M, Mendgen K (1989) The haustorial host-parasite interface in rust-infected bean leaves after high pressure freezing. Physiol Mol Plant Pathol 34: 519-530

Knox JP, Linstead PJ, King J, Cooper C, Roberts K (1990) Pectin esterification is spatially regulated within cell walls and between developing tissues of root apices. Planta 181: 512-521

(1992) Molecular probes for the plant cell surface. Protoplasma 167: 1-9

Larous L, Lösel D (1993) Strategies of pathogenicity in monokaryotic and dikaryotic phases of rust fungi, with special reference to vascular infection. Mycol Res 97: 415-420

Littlefield LJ, Heath MC (1979) Ultrastructure of rust fungi. Academic Press, New York

Low PS, Chandra S (1994) Endocytosis in plants. Annu Rev Plant Physiol Plant Mol Biol 45: 609 631

Mazau D, Rumeau D, Esquerré-Tugayé M-T (1988) Two different families of hydroxyproline-rich glycoproteins in melon callus. Plant Physiol 86: 540-546

Meikle PJ, Bonig I, Hoogenraad NJ, Clarke AE, Stone BA (1991) The location of (1-3)- $\beta$-glucans in the walls of pollen tubes of Nicotiana alata using a (1-3)- $\beta$-specific monoclonal antibody. Planta 185: 1-8

Mendgen K, Welter K, Scheffold F, Knauf-Beiter G (1991) High pressure freezing of rust infected plant leaves. In: Mendgen $\mathrm{K}$, Lesemann DE (eds) Electron microscopy of plant pathogens. Springer, Berlin Heidelberg New York Tokyo, pp 31-42

Moore PJ, Swords KMM, Lynch MA, Staehelin LA (1991) Spatial organization of assembly pathways of glycoproteins and complex polysaccharides in the Golgi apparatus of plants. J Cell Biol 112: 589-602

Oparka KJ, Wright KM, Murant EA, Allan EJ (1993) Fluid-phase endocytosis: do plants need it? J Exp Bot 44: 247-255

Pennell RI (1992) Cell surface arabinogalactan proteins, arabinogalactans and plant development. In: Callow JA, Green JR (eds) Perspectives of plant cell recognition. Cambridge University Press, Cambridge, pp 105-121

- Knox JP, Scofield GN, Selvendran RR, Roberts K (1989) A family of abundant plasma membrane-associated glycoproteins related to the arabinogalactan proteins is unique to flowering plants. J Cell Biol 108: 1967-1977

Puhlmann J, Bucheli E, Swain MJ, Dunning N, Albersheim P, Darvill AG, Hahn MG (1994) Generation of monoclonal antibodies against plant cell wall polysaccharides. I. Characterization of a monoclonal antibody to a terminal $\alpha-(1-2)$ linked-fucosyl-containing epitope. Plant Physiol 104: 699-710

Rijkenberg FHJ, Truter S (1973) Haustoria and intracellular hyphae in the rusts. Phytopathology 63: 281-286

Roberts K (1990) Structures at the plant cell surface. Curr Opin Cell Biol 2: $920-928$

Robinson DG, Hillmer S (1990 a) Endocytosis in plants. Physiol Plant 79: 94-104

- $\quad$ - (1990 b) Coated pits. In: Larsson C, Møller IM (eds) The plant 
plasma membrane. Springer, Berlin Heidelberg New York Tokyo, pp 233-255

Schmidt WE, Ebel J (1987) Specific binding of a fungal glucan phytoalexin elicitor to membrane fractions from soybean Glycine max. Proc Natl Acad Sci USA 84: 4177-4121

Sherrier DJ, Vandenbosch KA (1994) Secretion of cell wall oligosaccharides in Vicia root hairs. Plant J 5: 185-195

Smythe E, Warren G (1991) The mechanism of receptor-mediated endocytosis. Eur J Biochem 202: 689-699

Stark-Urnau M, Mendgen K (1993) Differentiation of aecidiosporeand uredospore-derived infection structures on cowpea leaves and on artificial surfaces by Uromyces vignae. Can J Bot 71: $1236-1242$

Steer MW (1988) Plasma membrane turnover in plants. J Exp Bot 39: 987-996

Woods AM, Gay JL (1987) The interface between haustoria of Puccinia poarum (monokaryon) and Tussilago farfara. Physiol Mol Plant Pathol 30: 167-185

Zhang GF, Staehelin LA (1992) Functional compartimentation of the Golgi apparatus of plant cells. Immunocytochemical analysis of high-pressure frozen- and freeze-substituted sycamore maple suspension culture cells. Plant Physiol 99: 1070-1083 